\title{
THE DEVELOPMENT OF SCIENTIFIC THINKING OF STUDENTS USING SIMULATIONS
}

\author{
Miriam SPODNIAKOVÁ PFEFFEROV $A^{*}$, Matej Bel University in Banská \\ Bystrica
}

Přijato: 16. 2. 2015 / Akceptováno: 25. 5. 2015

Typ článku: Výzkum

DOI: $10.5507 /$ jtie.2015.006

Abstract: Computer simulations have become a standard tool in physics education, mainly at universities. But this kind of the teaching aid can find its place at secondary schools as well.This paper introduces our investigations of the influence of the use of simulations within physics lessons at the secondary school on the students' knowledge in mechanics, specifically in kinematics, dynamics and the gravitational field. A pedagogical experiment was used as a research method and students' achievements were measured with a nonstandardised test. The obtained results are compared with the knowledge acquired by students who didn't use this kind of teaching aid during their physics lessons. In the next step, we have focused on the analysis of the impact

of the use of simulations on a development of students' scientific thinking.

Key words: simulation, physics education, research, mechanics.

\section{ROZVOJ PRÍRODOVEDNÉHO MYSLENIA ŽIAKOV PROSTREDNÍCTVOM SIMULÁCIÍ}

Resumé: V súčasnosti sú simulácie štandardnou súčastou vzdelávacieho procesu, prevažne na univerzitách. Tento druh učebnej pomôcky však môže nájst' svoje miesto aj na úrovni stredných škôl. Príspevok sa zaoberá vplyvom použivania simulácií $v$ rámci fyzikálneho vzdelávania na strednej škole na úroveñ vedomostí žiakov z mechaniky, konkrétne $z$ tematických celkov: kinematika, dynamika a gravitačné pole (experimentálna trieda). Uvedené tematické celky sú súčastou školskej fyziky v 1. ročníku. Výsledky žiakov $z$ experimentálnej triedy boli porovnávané $s$ výsledkami žiakov, ktorí nepouživali tento druh učebnej pomôcky (kontrolná trieda). V d'alšom kroku sme sa zamerali na analýzu vplyvu použivania simulácií na rozvoj prírodovedného myslenia žiakov.

Klíčová slova: simulácia, fyzikálne vzdelávanie, výskum, mechanika.

\section{ERIHPLUS}

*Autor pro korespondenci: miriam.spodniakova@umb.sk
This journal was approved on 2015-04-23 according to ERIH PLUS criteria for inclusion. 


\section{Introduction}

There have been many debates among experts concluding that the teaching of physics in Slovakia lacks an experimental approach. This fact was proven by a survey carried out within seven secondary grammar schools in Banská Bystrica region in the school year 2009/2010 (384 respondents between the ages of fifteen to nineteen). Only $49 \%$ of students said that the teacher had used demonstrations while explaining. Nonetheless $26 \%$ of students said they would appreciate a greater use of experiments (Krišková, 2011).

This is believed to be caused by a lack of the experimental equipment as well as by its obsoleteness, which was proven also by the results of the PISA survey: $75 \%$ of schools in Slovakia lack the material needed for laboratory exercises in science subjects (Národná správa, 2006). That is why students have only theoretical knowledge without being able to apply it to real tasks and problems.

Even though schools are less equipped with the needed aids, the PISA survey has proved that in terms of computer technology Slovakia's level is comparable with the OECD average. Since then several projects have contributed to the better quality of the information and communications technologies used at Slovak schools. Those digital technologies have a potential to improve teaching of science subjects even when the school is short of other experimental equipment and material.

Computer simulations and applets (sometimes referred to as physlets) that can be easily found on the Internet represent one of the opportunities how to demonstrate physics phenomena in the classroom. Both the simulations and applets are based on an exact mathematical model and they are themselves a visualisation of the given model. Simulations can be created only in a specific software, such as Interactive Physics, Modellus or Algodoo, etc. On the other hand, applets are the simulations programmed in the programming language Java and they can run only on the browser.

Simulations and/or applets should be a complement to the real experiment and a source of information for the student. They should not replace the real experiment in those school laboratories that enable its proper realisation. However, it is important to emphasise that simulations provide a proper visualisation of the studied phenomena, which can help learners to understand a difficult mathematical model of the physical reality (Holec, Murin, Raganová, 1998).

A research aimed at the study of the effect of the implementation of simulations in the teaching process is being carried out along with the development of new simulations designed to support physics education. Several studies have focused on the comparison of the traditional methods (explanation, real experiments (without a computer aid) and self-study) and teaching with the use of simulations. These show that the use of simulations in the teaching process has a positive impact on both the students' achievements and their ability to solve problem tasks (Steinberg, 2000), (Linn and Eylon, 2000), (Ronen and Eliahu, 2000), (Jimoyiannis and Komis, 2001), (Huffman, Goldberg and Michlin, 2003), (Zacharia and Anderson, 2003), (Holec, Spodniaková a Raganová, 2004), (Finkelstein et al., 2005), (Paetkau, Bissonnette and Taylor, 2013).

Despite of a good availability of simulations / applets on the Internet teachers have to cope with a few problems before they can incorporate the simulation use into the lesson plan:

1. The simulations are usually not provided in Slovak, which may limit their use by Slovak students. 
2. The simulations are likely to cover a variety of physical laws, which may determine their effective use in the teaching process.

3. The simulations are often physically not correct.

To eliminate those problems we have developed a set of simulations modelling phenomena in the field of mechanics. The simulations are accessible online at the web portal Physics around us (http://sparc.fpv.umb.sk /kat/kf/FON/). For an easier implementation into the teaching process, worksheets for the student as well as methodical sheets for the teacher were designed. To encourage student active learning, worksheets were created as a complement of the simulations that allow students to change the input parameters and to observe the changes on the diagram (Spodniaková Pfefferová and Holec, 2006). The worksheets bring a series of tasks for the student and serve as an inquiry-based learning tool. Students are stimulated to formulate their own assumptions and hypothesis, to analyse the obtained data and postulate the conclusions.

The use of such didactical approach requires a prior adjustment of student's cognitive processes by the teacher the way the student will gain essential and pedagogically defined information.

\section{The Use of Simulations within the Teaching Process}

The didactical efficacy of the developed set of simulations was verified within a pedagogical experiment conducted with $1^{\text {st }}$ year students at a 4-year secondary grammar school. Students of the experimental class studied three thematic units Kinematics, Dynamics and the Gravitational Field - with the help of the developed simulations and worksheets. The gained knowledge of experimental class students were then compared with achievements of students from a control class who were taught with traditional methods. Besides the comparison of the knowledge levels our further research interest included an identification of associated problem solving skills. In the next part we bring our findings concerning the thematic unit the Gravitational Field.

\section{The Procedure of the Pedagogical Experiment}

The experiment was running with 28 respondents of the experimental class (EC) and with 25 respondents of the control class (CC) in the school year 2007/2008. An important introductory criterion was to compare the students' knowledge level in physics in both classes. As the $1^{\text {st }}$ year students were involved, we were not able to take in consideration their previous assessment. That is why a non-standardised test was used to verify students' initial physics knowledge.

Control class students achieved the relative weighted score: $\mathrm{p}_{\text {average }}^{\mathrm{v}}=64,3 \%$ in the test whereas those from the experimental class achieved the relative weighted score: $\mathrm{p}_{\text {average }}^{\mathrm{v}}=63,7 \%$. The diagram shows the distribution of students' knowledge (Pic. 1). 


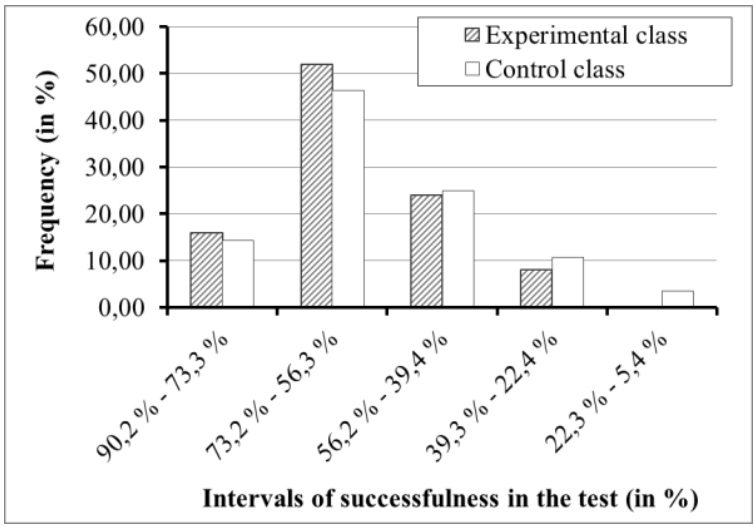

Pic. 1: Experimental and Control Class Students' Results from the Entrance Test

Subsequently a test relating to the difference of arithmetic means was carried out. This test did not prove the statistically significant difference (significance level $\alpha=5 \%$ ). We had small groups, so we used t-distribution for testing hypotheses, where the $t$-value was compared with the critical $t$-value $t_{\alpha ; f}(t=0,11$; critical $t$-value for the two-sided test is $\left.t_{0,05 ; 51}=2,00 ;|t|<t_{0,05 ; 51}\right)$.

Based on the criteria $|t|<t_{\alpha, f}$ we could take the null hypothesis $\mathrm{H}_{0}$ : The distributions of control class (CC) and experimental class (EC) students' knowledge were the same.

The teaching in the control class was carried out in a traditional manner. It includes explanations, demonstrations of experiments as well as a problem solving. Besides these traditional methods the simulations were used in the experimental class. Students were provided with worksheets, while the teacher could use the methodical worksheets, containing additional information. The lessons of the experimental class were carried out in a PC classroom that enabled the small group teamwork (two to three students being in one group). The same teacher taught the both classes and the both classes had allocated an equal time for physics.

\section{The Analysis of the Achieved Results}

A non-standardised didactical test was used to assess the students' knowledge.

The average score achieved in the test was to demonstrate the students' knowledge level. Since the number of tasks in the test did not exceed twenty, the compound score was employed, especially considering open-ended questions. These tasks were assessed with one point for each partial answer; thereafter the overall count of a particular task exceeded one. It is the author's subjective decision how to score tasks with a wide answer. It is then important to determine the average weighed score in lieu of the average score. The weighed score calculation is always preceded by the categorisation of the respective tasks, according to the taxonomy of educational objectives as described by B. Niemierko: remembering, understanding, specific and non-specific transfer which seems the most appropriate regarding science subjects. On the basis of belonging to the particular categories, the tasks were assigned their significance weights, e.g. tasks 
requiring comprehension were valued twice as much as tasks requiring only memorization.

The didactical test was designed for two groups - A and B - and was to be used in both classes in the same time (i.e. the same week) after the respective thematic unit had been explained. This prevented the results from being skewed - as the included questions might possibly have been familiar with some students. Before proper test taking, the students had been familiarised with the basic information regarding its completion. They were given 40 minutes to do the test. Some of the students handled the test before the deadline; the others did during the $40^{\text {th }}$ minute.

After the evaluation of the tests, the level of students' knowledge was expressed by means of relative weighed score. In addition to essential characteristics of the individual tests, arithmetic means were submitted to the test on its difference.

Each test presupposed a null hypothesis.

$$
\mathrm{H}_{0}: \bar{p}_{1}(\mathrm{CC})=\bar{p}_{2}(\mathrm{EC}) \text {, }
$$

where $\bar{p}$ refers to the average weighed score achieved in EC or CC. The significance level was set at the level $\alpha=0,05$. In case the null hypothesis is rejected, an alternative hypothesis is postulated.

$$
\mathrm{H}_{1}: \bar{p}_{1}(\mathrm{CC}) \neq \bar{p}_{2}(\mathrm{EC}) \text {. }
$$

Since there was an assumption that the use of simulations would contribute to the development of better skills in physics, the question was formulated as a one-sided test. When defining the assumption, we came out from the aforementioned results as well as from the studies realised abroad (Huffman, Goldberg and Michlin, 2003), (Jimoyiannis and Komis, 2001).

The test results show that EC students achieved $63,8 \%$ of points while CC students

\begin{tabular}{|c|c|c|c|}
\hline \multirow{2}{*}{\multicolumn{2}{|c|}{ Number of students $(n)$}} & $\mathrm{EC}$ & $\mathrm{CC}$ \\
\hline & & 28 & 28 \\
\hline \multirow{7}{*}{$\begin{array}{l}0 \\
0 \\
0 \\
0 \\
0 \\
0 \\
\frac{0}{00} \\
0 \\
3\end{array}$} & 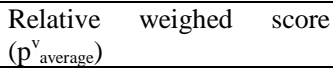 & $63,82 \%$ & $57,39 \%$ \\
\hline & Median $(p)$ & $76,79 \%$ & $70,53 \%$ \\
\hline & Standard deviation (s) & $12,28 \%$ & $12,47 \%$ \\
\hline & Variation margin $(\mathrm{R})$ & $45 \%$ & $52 \%$ \\
\hline & Variation coefficient (V) & $19,23 \%$ & $20,99 \%$ \\
\hline & $t$-value $(t)$ & 1,94 & \multirow{2}{*}{$t \mid>t_{0,05 ; 54}$} \\
\hline & Critical $t$-value $\left(t_{\alpha, \mathrm{f}}\right)$ & 1,67 & \\
\hline
\end{tabular}
only $57,4 \%$. The further statistics is listed below (Tab. 1).

Tab. 1: Statistics

A test concerning the difference of arithmetic means proved that it was a statistically significant difference $(\alpha=5 \%)$. According to the didactic test results $(t$-value $=1,94$, the critical $t$-value was $\left.t_{0,05: 54}=1,67\right)$, the null hypothesis $\mathrm{H}_{0}$ was rejected and the alternative hypothesis $\mathrm{H}_{1}$ was accepted $\left(|t|>t_{0,05: 54}\right)$ : The average experimental class students' weighed score is higher than that of control class students.

The distribution of students' performance is to be observed in the sequential in the diagram (Pic. 2). 


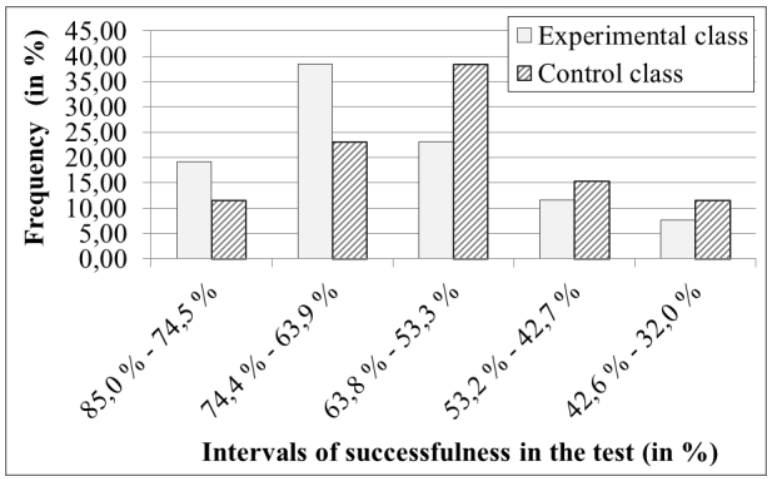

Pic. 2: Characteristics of EC and CC students' performance

The curve shifting referring to the distribution of experimental class students' performance towards a higher score obtained actually proves the alternative hypothesis. Some comparable results were obtained after the explanation of the thematic units Kinematics and Dynamics: experimental class students achieved significantly better results than those of the control class.

The data might be a bit older, yet we do consider the results to be relevant, owing to the fact that the didactical use of simulations was tested, which has only recently been put into practice in Slovakia. The results could not but prove the justified use of simulations within the teaching process.

\section{The Development of Scientific Thinking of Students Using Simulations}

When the experiment was being carried out, we were only concerned with the overall students' achievements - no deeper analysis was done. Nonetheless, lately there has been an emphasis on the stimulation for student class activities and on a development of scientific thinking. Thus, we decided to re-evaluate the gained data with a focus on the possible impact of the simulations use on the development of scientific thinking of students.

As mentioned, the tasks in the research test were divided according to Niemierko's taxonomy of educational objectives into the following categories: remembering, understanding, the specific and the non-specific transfer. It was then possible to examine the impact of the use of simulations on different levels of learning (Pic. 3). 


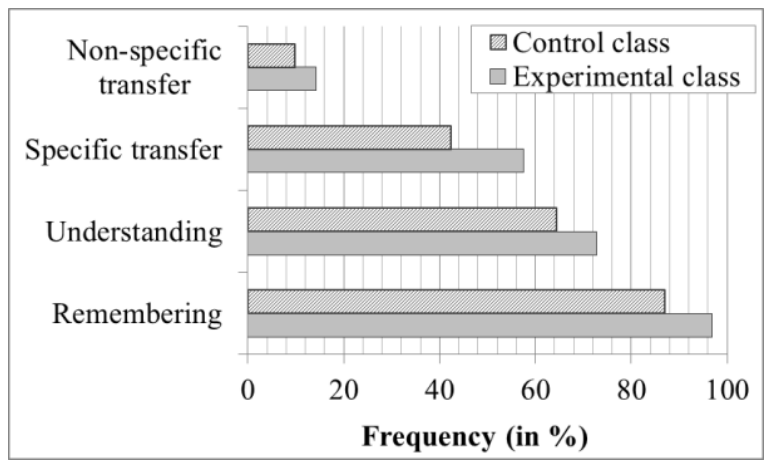

Pic. 3: Successfulness of students in particular categories

The diagram clearly shows that once the thematic unit Gravitational Field had been explained, both EC and CC students obtained the best results from tasks requiring remembering. On the other hand, the students had the worst assessment of tasks requiring a creative approach (non-specific transfer). Nevertheless, it is possible to conclude that the use of simulations had a positive impact on each EC students' learning level. The test concerning the difference of arithmetic means did prove the significant difference of two levels: remembering (relative weighed score: $\bar{p}_{E C}=96,3 \%, \bar{p}_{C C}=87,0 \%$; $t$-value $=3,45)$ and the specific transfer $\left(\bar{p}_{E C}=57,6 \%, \bar{p}_{C C}=42,4 \% ; t\right.$-value $=$ 1,97). The tasks requiring higher learning levels (understanding and non-specific transfer) did not prove any statistically significant differences. This fact might be explained by means of the abstractness of the topic that is likely to be misunderstood when compared to other topics, such as Kinematics and Dynamics.

This statement is even supported by the students' results after the explanation of these thematic units had been provided. EC students were actually assessed better than CC students. As for Kinematics, the following significant differences were examined: understanding $\left(\bar{p}_{E C}=44,7 \%, \bar{p}_{C C}=36,5 \% ; t\right.$-value $\left.=1,82\right)$, specific $\left(\bar{p}_{E C}=34,6\right.$ $\%, \bar{p}_{C C}=22,0 \% ; t$-value $\left.=3,68\right)$ and non-specific transfer $\left(\bar{p}_{E C}=23,6 \%, \bar{p}_{C C}=\right.$ $16,0 \% ; t$-value $=1,69)$. The students' results after the explanation of thematic unit Dynamics showed a statistically important difference regarding the learning levels: remembering $\left(\bar{p}_{E C}=74,6 \%, \quad \bar{p}_{C C}=64,8 \%\right.$; $t$-value $=2,98)$, understanding $\left(\bar{p}_{E C}=47,3 \%, \bar{p}_{C C}=18,5 \% ; t\right.$-value $\left.=3,83\right)$ and non-specific transfer $\left(\bar{p}_{E C}=48,1 \%, \bar{p}_{C C}=17,9 \% ;\right.$-value $\left.=5,91\right)$.

Considering the interpreted results, it follows the positive impact of the use of simulations on students' getting familiar with the topic unit as well as their creative thinking necessary for the problem tasks solving. 


\section{Conclusions}

The results obtained within the pedagogical experiment can be described as follows:

- The use of simulations along with the worksheets for the student and the teacher contributed to a greater experimental class students' knowledge in physics.

- Based on the sit-in-a-class in the both experimental and control classes, it is possible to state that the teaching process with the use of simulations provides students with a plenty of possibilities for an active work, as opposed to the traditional teaching.

- The use of simulations allows students to work independently as well as to improve their abilities to work in a team.

Considering the previous experience, it is possible to postulate that the use of simulations will enhance the teaching process and new methods contributing to a quality teaching.

\section{Acknowledgement}

Contribution was elaborated within the project KEGA no. 022UMB-4/2012 named The Use of New Methods and Forms in Teacher Training and Teaching of Their Students with Emphases on Development of Science Competitions.

\section{Bibliography}

Finkelstein, N. D., Adams, W. K., Keller, C. J., Kohl, P. B., Perkins, K. K., Podolefsky, N. S. \& Reid, S. (2005). When learning about the real world is better done virtually: A study of substituting computer simulations for laboratory equipment. Physical Review Special Topic - Physics Education Research 1, 010103.

Holec, S., Murin, M. \& Raganová, J. (2000). Modelové a reálne experimenty podporované počítačom. In: Zborník z Medzinárodnej vedeckej konferencie Fyzikálne vzdelávanie dnes a po roku 2000 (Physical Education Today and After 2000). Prešov: The Department of Physics, Faculty of Humanities and Natural Sciences, The University of Prešov, 1998, pp. $79-82$.

Holec, S., Spodniaková Pfeferová, M. \& Raganová, J. (2004). Computer Simulations in Mechanics at the Secondary School. Informatics in Education. Vol. 3, No. 2(2004), pp. 229-238.

Hufmann, D., Goldberg, F. \& Michlin, M. (2003). Using Computers to Create Constructivist Learning Environments: Impact on Pedagogy and Achievement. Journal of Computers in Mathematics and Science Teaching, 22(2), pp. 151-168. Norfolk.

Jimoyiannis, A. \& Komis, S. (2001). Computer simulations in physics teaching and learning: a case study on students' understanding of trajectory motion. Computers \& Education, Volume 36, Issue 2. pp. 183-204.

Krišková, K. (2011). Experimenty ako súčast’ vyučovania fyziky na strednej škole. Bachelor's Thesis. Banská Bystrica FNS MBU.

Linn, M. C. \& Eylon, B. (2000). Knowledge Integration and Displaced Volume. In: Journal of Science Education and Technology. Vol. 9, No. 4.

Národná správa OECD PISA SK 2006. [online]. [cit. 2014-08-08]. Available at: <http://www.nucem.sk/sk/medzinarodne_merania/project/5\#422,o558>

Paetkau, M., Bissonnette, D. \& Taylor, C. (2013). Measuring the Effectiveness of Simulations in Preparing Students for the Laboratory. The Physics Teacher, Volume 51, Issue 2. 
Ronen, M. \& Eliahu, M. (2000). Simulation - a bridge between theory and reality: the case of electric circuits. In Journal of Computer Assisted Learning. Volume 16, Issue 1, pp. $14-26$.

Spodniaková Pfefferová, M. \& Holec, S. (2006). Using Simulations in Physics Education. In: GIREP Conference 2006. Modelling in Physics and Physics education: August 20-25 Amsterdam, Netherlands: program and abstracts. Amsterdam: Universiteit van Amsterdam.

Steinberg, R. S. (2000). Computers in teaching science: To simulate or not to simulate? American Journal of Physics. Volume 68, Issue S1.

Zacharia, Z. \& Anderson, O. R. (2003). The effects of an interactive computer-based simulation prior to performing a laboratory inquiry-based experiment on students' conceptual understanding of physics. American Journal of Physics, Volume 71, Issue 6. 